UDC 316:331.5:378

Hasmik HOVHANNISYAN,

Hovhannes HOVHANNISYAN,

Astghik PETROSYAN

\title{
YOUNG PROFESSIONALS' \\ LABOUR MARKET INTEGRATION ISSUES IN ARMENIA: \\ A CASE STUDY WITH SPECIAL REFERENCE TO ALUMNI OF \\ ARMENIAN STATE PEDAGOGICAL UNIVERSITY
}

\begin{abstract}
The article is devoted to the analysis of university and labour market relationship. In addition to economic analysis, studying the involvement process of young people in the labour market is essential to identifying the link between higher education institutions (HEIs) and the labour market in order to assess and implement appropriate policies. This case study was conducted to discover the integration process of the classes of 2014, from three faculties of Armenian State Pedagogical University, in Armenia's labour market. The research reveals the demand for these professions in the labour market and the pace of finding jobs. The article discusses the factors that hinder or contribute to the process of integration of young specialists in the labour market, as well as, the advantages and disadvantages of HEIs from young professionals' perspective. Methodological recommendations and guidelines on the organisation of higher education following the labour market requirements are offered in the discussion section. It is significant to develop mechanisms for promoting employers' involvement in management offices and faculties of HEIs, to develop and fix legal norms, to improve the methodological principles and plans regarding the organisation of the practicum practices. It is proposed to expand the functions and role of career centres created in HEIs in order to establish the university's activity by the labour market requirements and to assist graduates in the labour market as well as provide continuous professional development programs and training for the teaching staff.
\end{abstract}

Keywords: labour market, demand, HEI alumni, employment, unemployment, improving higher education.

Predictions in the field of the labour market and university relations, issues of short-term and long-term projects are the significant challenges of professional education management in the modern world which adopted the liberal economic system. In this regard, the United Nations
Development program sponsors various policy development and reform programs. Since 1994, studies have been undertaken by the European Union's Education Foundation in the area of harmonising the relationship between the vocational education and labour market. The goal is 
Young Professionals' Labour Market Integration Issues in Armenia: a Case Study with Special Reference to Alumni of Armenian State Pedagogical University

to reform education policy by adjusting it to economic developments and changes in the labour market ${ }^{1}$. Economic analysis of labour market, ongoing monitoring and studies on the involvement of young professionals in the labour market are significant for revising the previous planning traditions of economic sectors, regarding HEIlabor market relations regarding assessment and policy implementation. Thus, this study was conducted to reveal the current issues and relations between the labour market and one of the HEIs in Armenia.

\section{Method}

The research was conducted in the Armenian State Pedagogical University (ASPU) named after Khachatur Abovian among young professionals who graduated in the academic year 2013-2014. The sample of the research was formed in a multilevel manner based on the principles of the root, stratification and proportional representation. One faculty from each of the following categories was chosen: social sciences, quantitative sciences and pedagogical education. The faculties of Philology (Armenian language and literature); Mathematics, Physics and Informatics, and Primary Education were selected through random sampling. Then, 206 undergraduate and graduate alumni were randomly selected for the research. A structured interview was

See for example: Rynki truda $i$ vozmozhnosti trudoustroistva. Tendentsii i problem v Armenii, Azerbaidzhane, Belarusi, Gruzii, Respubliki Moldova $i$ Ukraine (Labor Markets and Employment Opportunities. Trends and Challenges in Armenia, Azerbaijan, Belarus, Georgia, the Republic of Moldova and Ukraine, in Russian). ETF, Luxembourg, 2011. Retrieved October 28, 2018 form:

https://www.etf.europa.eu/sites/default/files/m/149960 3357207EFFC125798F004A2EBE Labour\%20mark ets $\% 20 \% 26 \% 20$ employabilityRU.pdf;

https://www.etf.europa.eu/en conducted by phone from May 20 to June 30, 2018.

\section{Results}

\section{ASPU Graduates in Armenian Labour Market}

Four years after graduating from the university, $66.5 \%{ }^{2}$ of those surveyed have some income-generating jobs in the labour market. Apropos, as for 2005, a study was conducted by the Ministry of Education and Science of the Republic of Armenia and the United Nations Development Programme (UNDP) Armenia, according to which the total employment percentage of graduates in 2002 was 59.5\% (National Policy for Professional Education: Concept Paper, 2005, p. 25).

According to the survey results, male participants were more successful in the labour market than the females, even if they served in the army for two years.

In 2018, as of May-June (4 years after graduation), $100 \%$ of the male graduates of 2014 had jobs, whereas only the $64.4 \%$ of females had jobs. The $17.5 \%$ of females were still in the process of finding jobs (see Chart 1). The unemployed $18.1 \%$ of the female respondents considered themselves as voluntarily unemployed. It is worth mentioning that $13.9 \%$ of them were housewives.

2 According to the research conducted by the RA Statistical Committee, in 2017, the employment rate for the ages of 25-29 was 53.4\%. See Hayastani Hanrapetut'yan social-tnteskan vitwaky' 2018 t'vakani hunvar-martin (The Social-Economical Situation of the Republic of Armenia January-March, 2018, in Armenian). Retrieved October 15, 2018 form: https://www.armstat.am/file/article/sv 03 18a 141.pd f; https://www.armstat.am/am/?nid=82\&id=2029, p. 102. 
Chart 1.

Employment and Unemployment Rates of 206 Graduates (class of 2014) of ASPU, as of MayJune, 2018

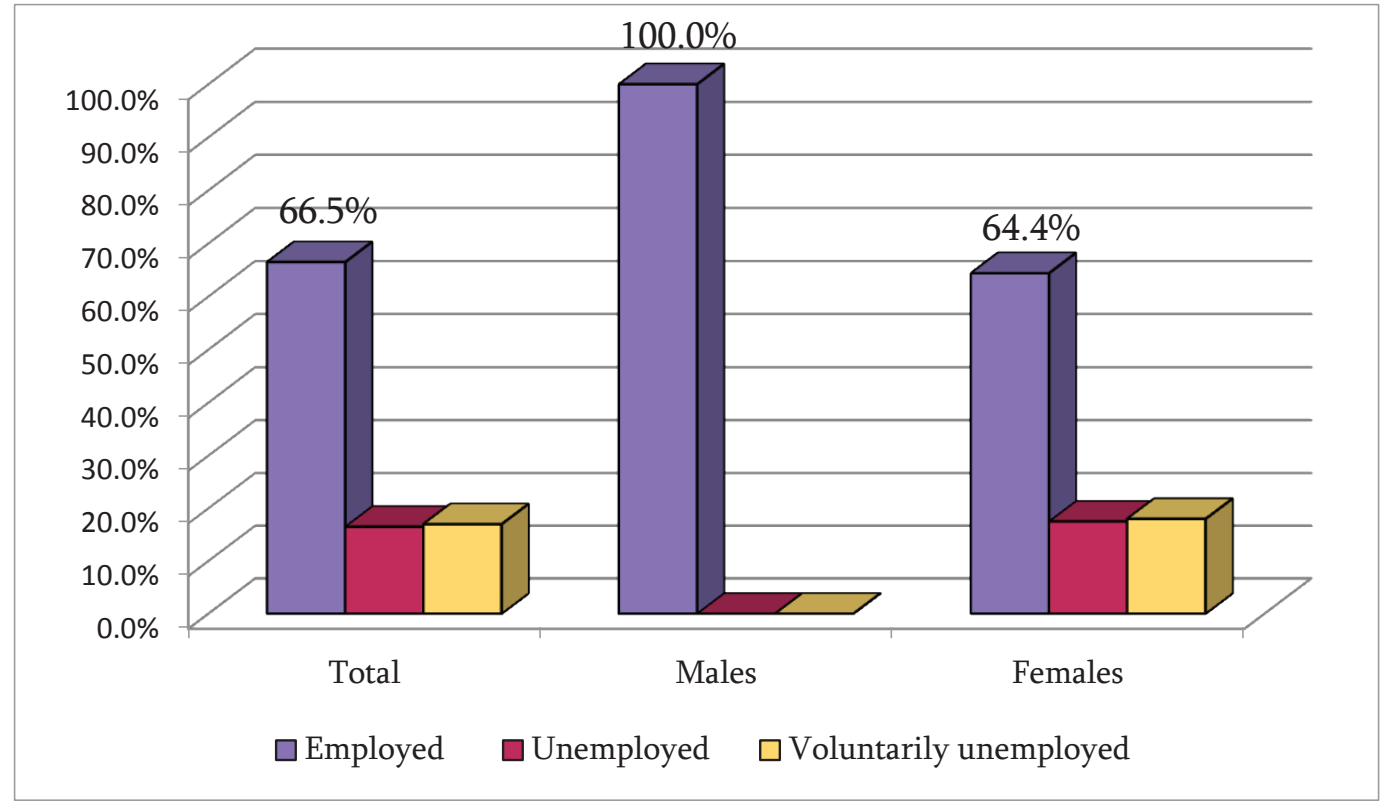

Employment and unemployment rates are different according to the studied professions. The employment rate of the participants from the Faculty of Mathematics, Physics and Informatics
(72.7\%) was higher than the rate of the respondents from the Initial Education (67.1\%) and the Philology (58.6\%) faculties (see Chart 2).

Chart 2.

Employment and Unemployment Rates Amongst ASPU's Three Faculty Graduates (N=206)

PEilology


What are the reasons behind the unemployment of $33.5 \%$ of the respondents 4 years after graduating from ASPU?

The $24.8 \%$ of the participants $(73.9 \%$ of those unemployed) explained that they were unemployed because of family and personal reasons. It is worth mentioning that such response was received entirely from the female participants.

The $4.4 \%$ of the respondents ( $13 \%$ of those unemployed) couldn't find jobs compatible with their professional qualifications. This number is comprised of $5.2 \%$ of graduates of Philology and $7.3 \%$ of the Primary Education faculties. Meanwhile, none of the graduates of the Mathematics, Physics and Informatics faculty agreed to this reason.

The $1.5 \%$ of the respondents said they were unemployed because of the conditions and the respective compensation offered in the labour market. This reason was given by $4.3 \%$ of the unemployed respondents (see Chart 3).

Chart 3.

Main Reasons for Unemployment Mentioned by the Participants

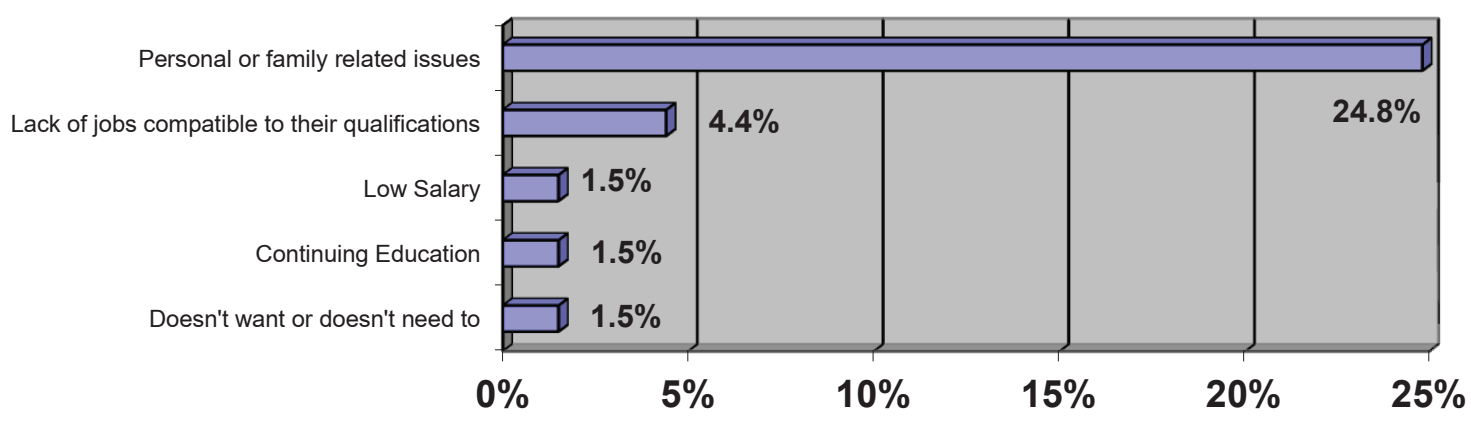

According to the research results, $63.6 \%$ of the participants had a stable and permanent job. The jobs of $2.9 \%$ respondents were unstable and temporary.

Not all respondents' employment corresponds to the profession they received at the university. $50.5 \%$ of the participants had oc- cupations that completely $(30.6 \%)$ or somewhat $(19.9 \%)$ corresponded to their educational qualifications. However, $16 \%$ of young professionals had jobs that were somewhat (5.3\%) and ultimately (10.7\%) irrelevant to their educational qualifications (see Chart 4). 
The Compatibility of the Participants' Education and Employment

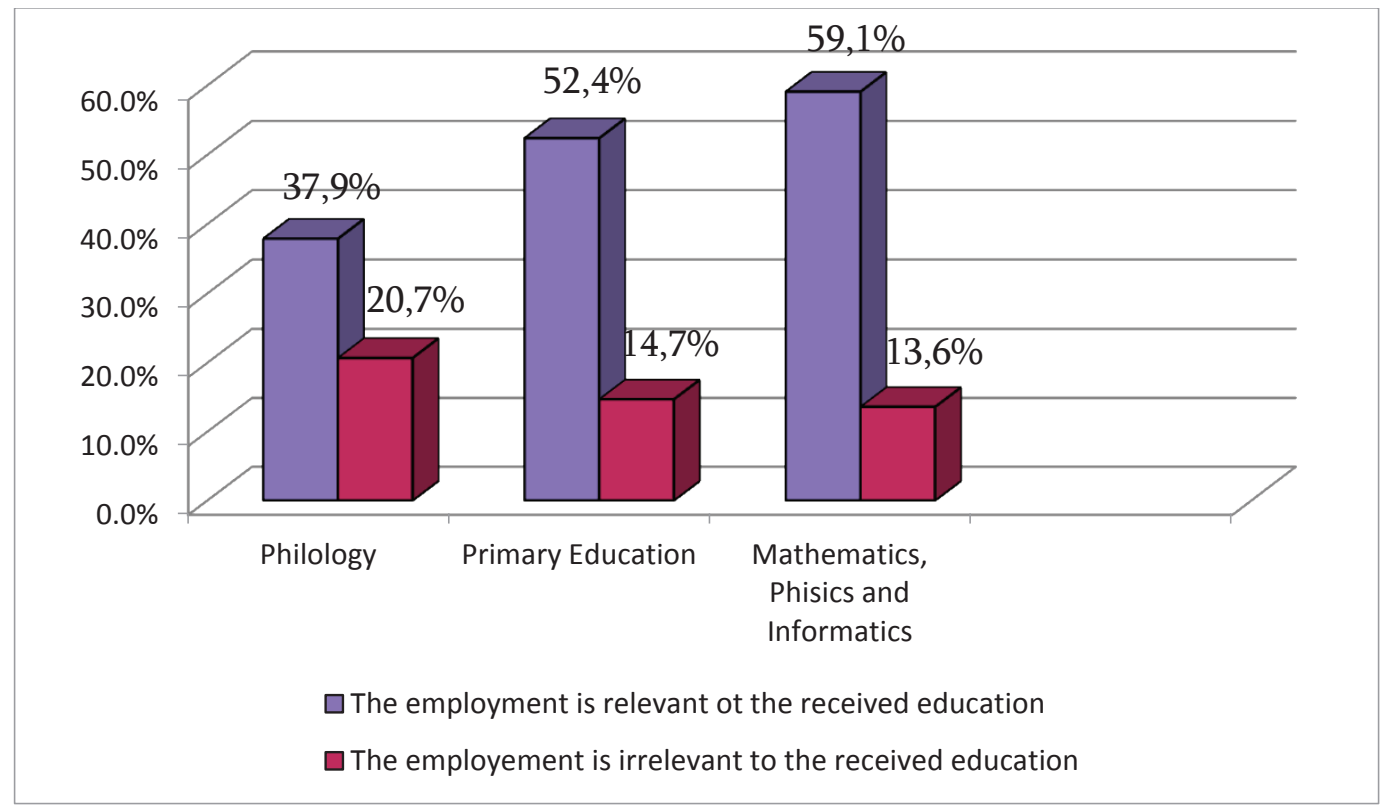

The $74.5 \%$ of the interviewed alumni worked in private sectors. Only $4.4 \%$ of the reworked in state institutions, whereas the $21.1 \%$ spondents had their own business (see Chart 5).

Chart 5 .

The Integration of 206 ASPU Graduates (class of 2014) in the Labor Market:

\section{Public vs Private Sectors}

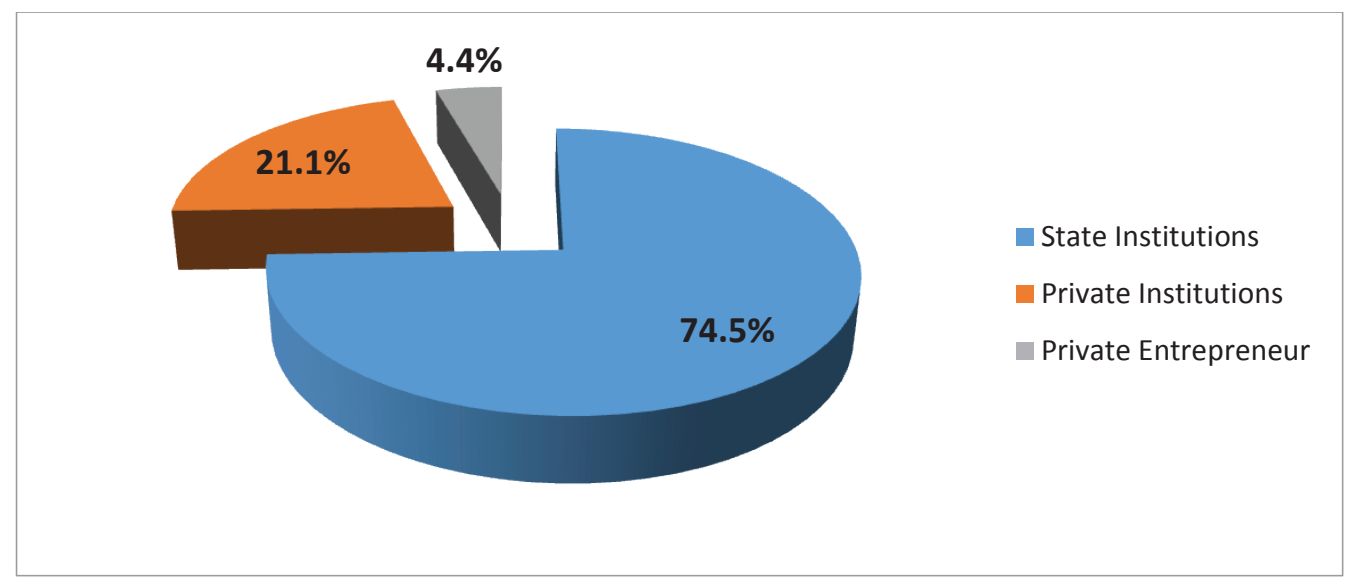

Most of the employment is accounted for educational and scientific institutions (70.1\%). The $59.1 \%$ was state-owned, and the $11.0 \%$ was privately owned preschools, schools, secondary specialized educational institutions, universities, etc. The $11.6 \%$ of the participants were integ- rated into the trade (5.8\%) and various private service-providing institutions (5.8\%). The $4.4 \%$ of the respondents had jobs in finance-related fields. Next, 3.6\% were employed in local, regional and public administration bodies and another $3.6 \%$ in cultural institutions. The rest of the 
respondents were employed in industry, agricul-

agencies (see Chart 6).

ture, health, armed forces and law enforcement

Chart 6.

The Participants' Employment Division Based on Economic Sectors

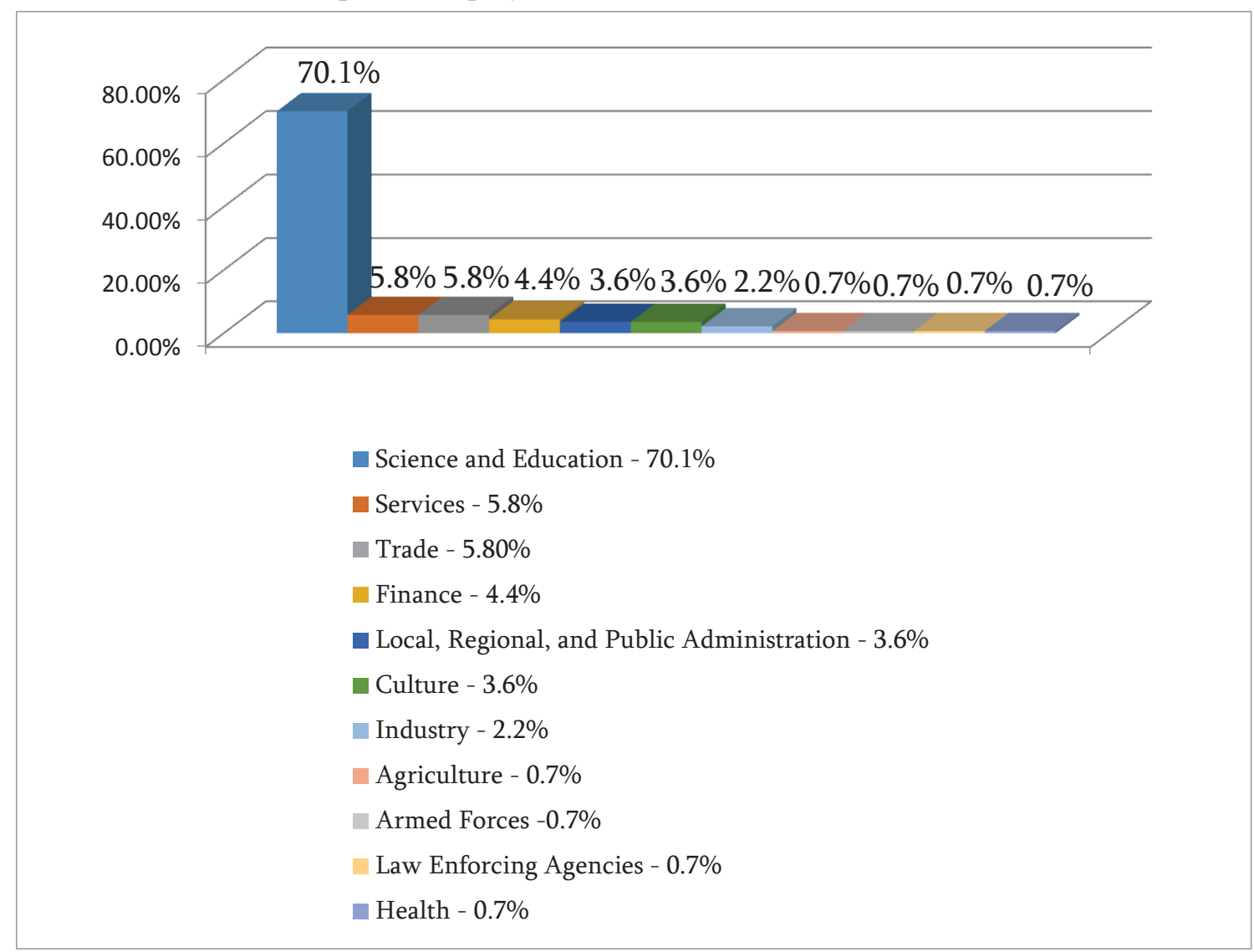

How long did it take the participants to find their jobs?

The average time spent on finding a job amongst participants who had stable employment was 5.4 months. The respondents that graduated from the Philology faculty spent 9.3 months, Primary Education faculty alumni spent 4.9 months, and the Mathematics, Physics and Informatics former student spent about 3.1 months on finding a job (see Chart 7). 
Chart 7.

The Stable Employment Dynamics of Class of 2014 Until the $1^{\text {st }}$ Half of 2018

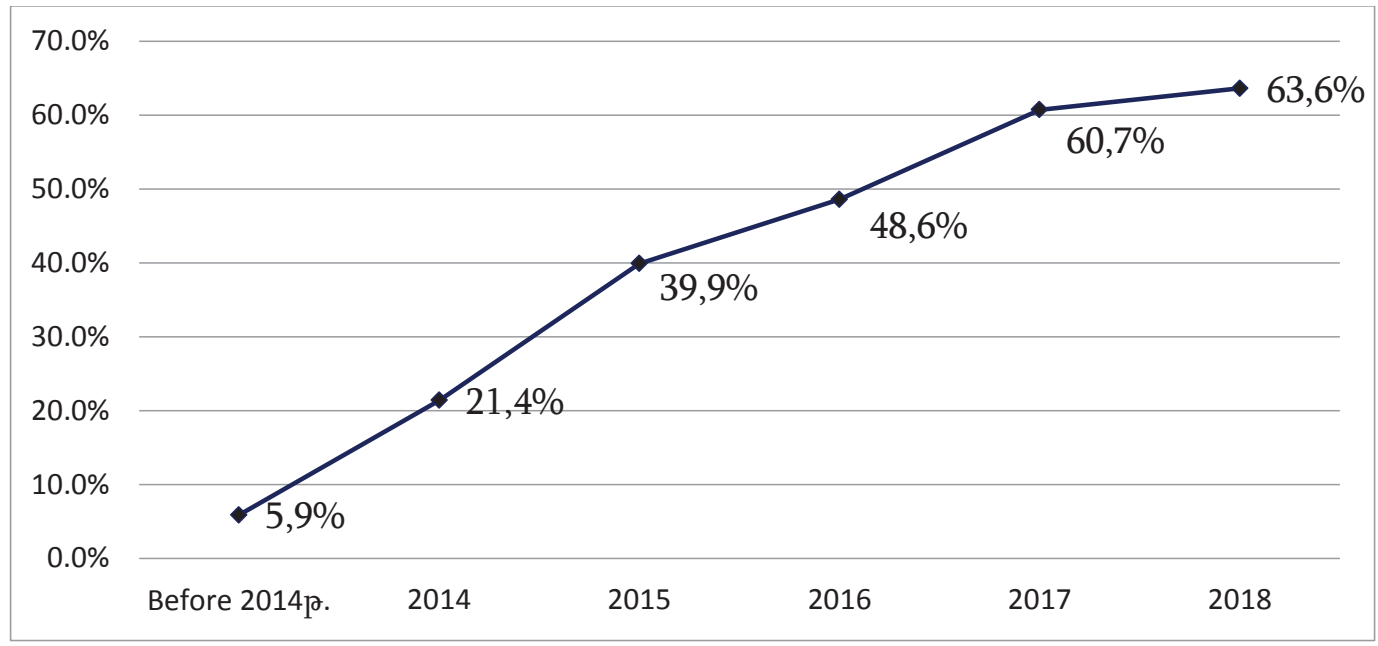

What factors affected on the participants' choice of their jobs?

shows that processes and relationships in this field are characterised by weak, institutional, and spontaneous description (see Chart 8).

The analysis of the answers to this question

Chart 8 .

The Role of Various Factors in Finding a Stable and Permanent Job

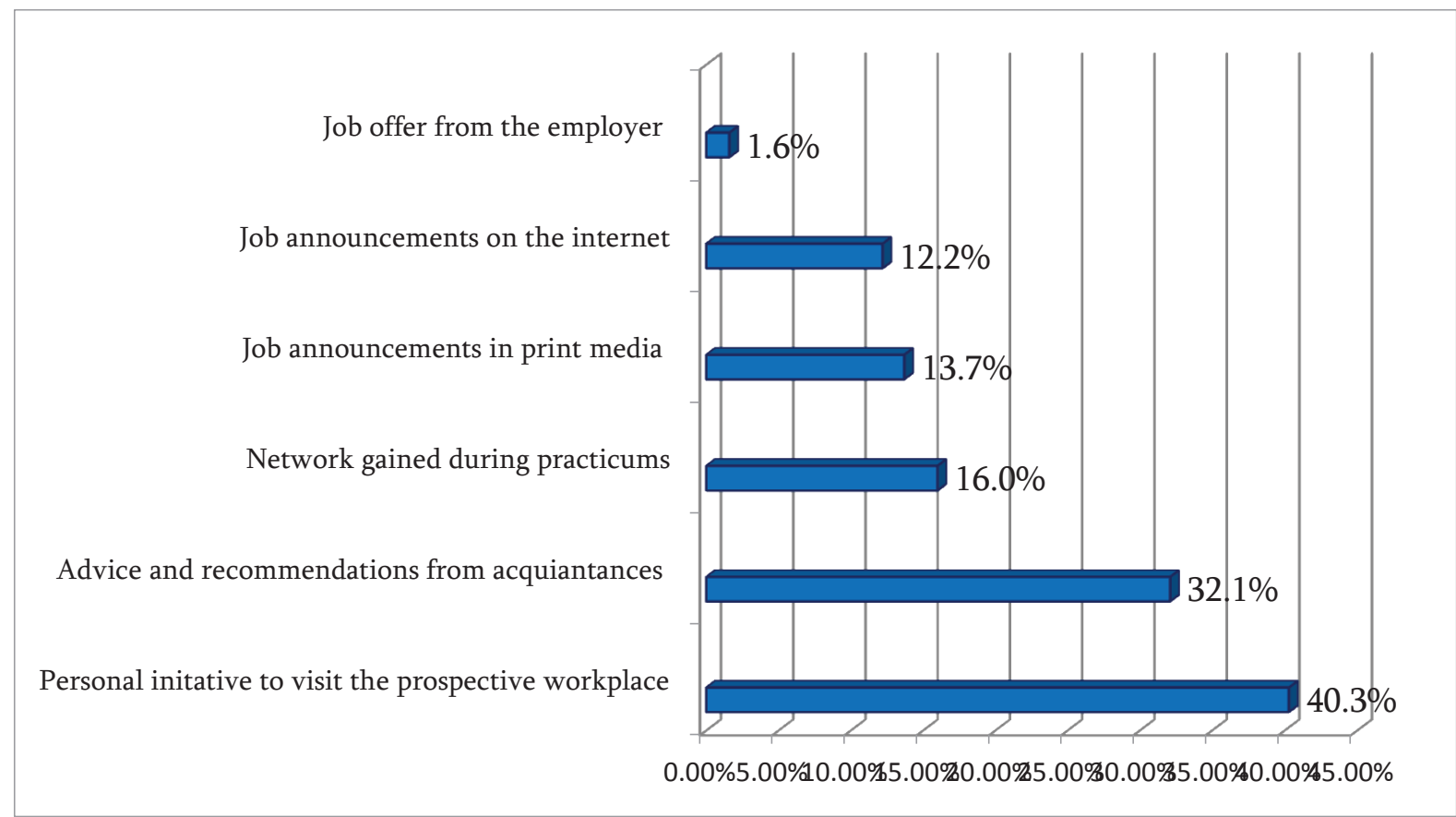

The results of the study confirm that employment rates and opportunities in the labour market are directly proportional to the academic achievement indicators of young professionals 
and the level of knowledge. It is important to state that $61.8 \%$ of graduates with average academic standing had jobs. The $45.1 \%$ had jobs if those corresponded to their specialisation received at the university. The correlation between graduates with high academic standing was $78.7 \%$, and for the graduates who worked in the higher education field, the rate was $63.9 \%$.

\section{Attractive and Concerning Aspects of Labor Market}

The results of the study prove that the main concerns that the target-group young professionals have concerned the labour market as of low compensation. The $66.4 \%$ of the respondents believed that the job payments are insufficient for buying an apartment, furniture, and car. However, the $43.1 \%$ thought that the payment rates are unsatisfactory even for basic family expenses. The $29.9 \%$ of the participants considered their salaries entirely or mostly satisfactory. Based on the interview results, the average amount of salary that the young professionals get is 97.992 AMD. Moreover, male participants happened to earn more (143.333 AMD) than the female participants (94.533 AMD). There are also some differences between the salaries of young professionals working in Yerevan and other towns or rural areas (see Chart 9).

Chart 9.

Average Monthly Salary of the Participants in Yerevan and Other Regions (AMD)

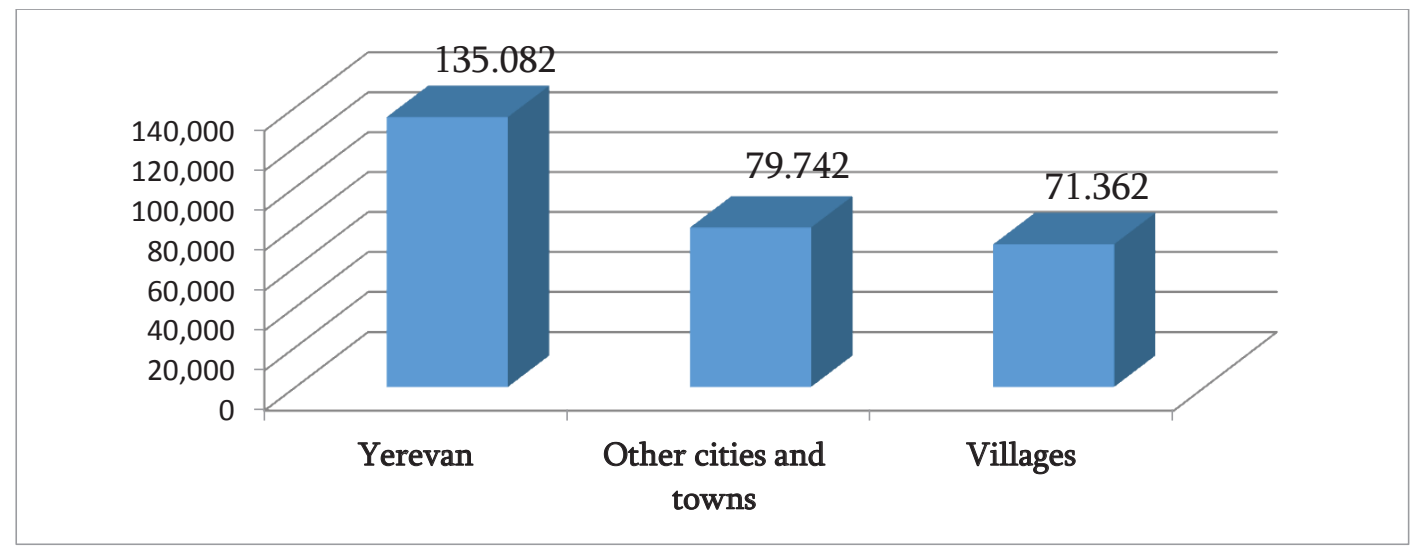

The $72.3 \%$ respondents found the opportunity of self-expression and mental satisfaction to be the most attractive aspects of their employment. Other attractive factors were revealed to be the respect and reputation $(70.1 \%){ }^{1}$

Then come the interest of the work
$(63.5 \%)^{2}$, the opportunities provided for the use of professional skills and knowledge (62.0\%), the creative approach and the possibilities of implementing their initiatives $(61.3 \%)$, free time, (48.9\%).

2 The work is more attractive in terms of engaging in professional activities for the graduates of the faculty of Mathematics, Physics and Informatics 70,8\% in comparison with the specialists of Primary Education faculty $-67,3 \%$ and philologists $-47,1 \%$. 
The University Knowledge and the Process of

Professors' Professional Development from the Graduates' Perspective

The $55.3 \%$ of respondents consider the knowledge gained in the university sufficient to become a full-fledged professional and to find a $\mathrm{job}^{3}$. The $32.0 \%$ of the respondents consider the knowledge gained considerably sufficient for the labour market requirements. The degree of satisfaction with the knowledge gained at the university is somewhat more noticeable amongst the graduates of Philology and Primary Education faculties.

What are the weak aspects of the knowledge gained at the university from the point of view of the labour market requirements and omissions that, according to respondents, negatively affects the university education process?

Among the disadvantages, $26.2 \%$ of the respondents mentioned the lack of practice and too much focus on theoretical knowledge. Next, $14.1 \%$ of the former students thought that the taught knowledge is outdated. Lastly, $8.3 \%$ of the participants commented that the nature of educational-industrial practicum is incomplete.

The $6.8 \%$ of the respondents had a more self-critical approach and found that not all students have a strong desire and discipline to work on becoming full-fledged specialists. Only $3.9 \%$ of those interviewed stated that the existing tech-

\footnotetext{
${ }^{3}$ According to the results of the survey conducted in 2005 by the UNDP Experts Group within the graduates of 25 universities $54,8 \%$ of respondents responded positively to this question, the received knowledge has considered partially satisfactory $28,6 \%$, not satisfactory $16,6 \%$. See National Policy for Professional Education: Concept Paper. Yerevan, 2005, p. 38. Retrieved October 12, 2018 form: http://un.am/up/library/National\%20Policy Prof Educ eng.pdf.
}

nical and organisational issues hinder the educational process.

The graduates were asked to evaluate the process of preparing a specialist with the example of their faculty where 1 point stood for very bad and 5 points for excellent. Overall, the respondents assessed the process fairly high. The average score was calculated to be 4.0 point $^{4}$.

However, as previously reported by other researchers, while evaluating their professional education process and their knowledge and abilities, the young professionals are somewhat more generous than the employers who assess the theoretical and practical capacities of young professionals who have been employed relatively modest (see National Policy for Professional Education: Concept Paper, 2005, p. 72).

\section{Conclusion}

The results of the previous surveys and their comparative analysis allow us to notice that the rates and opportunities for employment in the labour market are increasingly conditioned by the academic achievements and knowledge of young professionals. Instead, the role of friends' advice and family recommendations regarding employment choice is decreasing.

There is a constant problem of progressive harmonisation of university education and workplace requirements, and continuously updating the issues of education norms. In this regard, it is

4 According to the results of the survey the University Process of Preparing Specialists by the Example of their Own Faculty conducted in 2005 by the UNDP Experts Group within the graduates of 25 universities by 42 specializations the similar average statistical score was obtained 3,998 point. National Policy for Professional Education: Concept Paper. Yerevan, 2005, p. 38-39. Retrieved October 12, 2018 form: http://un.am/up/library/National\%20Policy_ProfEduc e ng.pdf. 
Young Professionals' Labour Market Integration Issues in Armenia: a Case Study with Special Reference to Alumni of Armenian State Pedagogical University

essential to establish legal mechanisms to ensure that the stakeholders are involved in university management systems. It will give a wide range of opportunities to take into account employers' needs in organising trainings, curricula and syllabi matching the young professionals' prospective employment. The significant involvement of employers in the management and faculty councils will also have a positive impact on the improvement of the law-making practices and their role.

Perhaps, it is also necessary to reform the methodological principles and plans for the organisation of production (outsourcing), which is an essential component of vocational education, by appointing advisor-managers and direct supervisors as well as analysing reflection reports submitted by learners.

In order to develop the relationship between universities and the labour market and promote the graduates in the labour market, it is necessary to expand the functions and role of career centres established in HEIs. Throughout these developments it is significant to consider the following:

studying the target offers and demands of the labour market, maintaining communication with graduates of the university with the use of new informational technologies, coordinating and analysing graduates' professional biography and career;

presenting reports on the management and development of educational programs;

$>$ developing a database of student and faculty alumni;

supplying university graduates with fresh information on labour market demand, such as invitations on a regular basis;

organising professional development programs and trainings for graduates.
One of the most important means of raising the level of education and contemporary content is the formation of a stable tradition and system of professional development of the teaching staff. There is still no difference in the labour market between the Bachelor's and Master's graduation certificates and diplomas. The exception is the admission for postgraduate studies only.

Perhaps it would be right to be consistent and legislatively fix the list of all positions (first of all for budgetary workers: leading professionals, senior or senior positions, etc.), which require a master's degree. Notably, it is advisable to legislate mandatory occupation of certain positions (to optimize the master's degree during the announced vacancy announcements with certain years of professional work experience).

\section{REFERENCES}

Hayastani Hanrapetut'yan social-tnteskan vitwaky' 2018 t'vakani hunvar-martin (The Social-Economical Situation of the Republic of Armenia JanuaryMarch, 2018, in Armenian). Retrieved October 15, 2018 form: https://www.armstat.am/file/article/sv 03 18a 141.pdf; https://www.armstat.am/am/?nid=82\&i $\mathrm{d}=2029$.

National Policy for Professional Education: Concept Paper. Yerevan, 2005. Retrieved October 12, 2018 form: http://un.am/up/library/National\%20Pol icy_ProfEduc_eng.pdf.

Rynki truda i vozmozhnosti trudoustroistva. Tendentsii i problem v Armenii, Azerbaidzhane, Belarusi, Gruzii, Respubliki Moldova i Ukraine (Labor Markets and 
Employment Opportunities. Trends and Challenges in Armenia, Azerbaijan, Belarus, Georgia, the Republic of Moldova and Ukraine (in Russian)). ETF, Luxembourg, 2011. Retrieved October 28, 2018 form: https://www.etf.europa.eu/sites/default/ files $/ \mathrm{m} / 1499603357207 \mathrm{EFFC} 125798 \mathrm{~F}$ 004A2EBE Labour $\% 20$ markets $\% 20 \%$ 26\%20employabilityRU.pdf; https://www.etf.europa.eu/en. 